\title{
Technical Progress Report on Application and Development of Appropriate Tools and Technologies for Cost-Effective Carbon Sequestration
}

\author{
Quarterly Report \\ July -September 2005 \\ Principal Authors: \\ Bill Stanley \\ Patrick Gonzalez \\ Sandra Brown \\ Sarah Woodhouse Murdock \\ Jenny Henman \\ Zoe Kant \\ Gilberto Tiepolo \\ Tim Pearson \\ Neil Sampson \\ Miguel Calmon
}

Date Issued: October 2005

Cooperative Agreement No. DE-FC-26-01NT41151

Submitting Organization:

The Nature Conservancy

4245 North Fairfax Drive

Suite 100

Arlington, Virginia 22203

Primary Subrecipients:

Winrock International

1611 North Kent Street

Arlington, VA 22209 


\section{DISCLAIMER}

This report was prepared as an account of work sponsored by an agency of the United States Government. Neither the United States Government nor any agency thereof, nor any of their employees, makes any warranty, express or implied, or assumes any legal liability or responsibility for the accuracy, completeness, or usefulness of any information, apparatus, product, or process disclosed, or represents that its use would not infringe privately owned rights. Reference herein to any specific commercial product, process, or service by trade name, trademark, manufacturer, or otherwise does not necessarily constitute or imply its endorsement, recommendation, or favoring by the United States Government of any agency thereof. The views and opinions of authors expressed herein do not necessarily state or reflect those of the United States Government or any agency thereof. 


\begin{abstract}
The Nature Conservancy is participating in a Cooperative Agreement with the Department of Energy (DOE) National Energy Technology Laboratory (NETL) to explore the compatibility of carbon sequestration in terrestrial ecosystems and the conservation of biodiversity. The title of the research project is "Application and Development of Appropriate Tools and Technologies for Cost-Effective Carbon Sequestration”.

The objectives of the project are to: 1) improve carbon offset estimates produced in both the planning and implementation phases of projects; 2) build valid and standardized approaches to estimate project carbon benefits at a reasonable cost; and 3) lay the groundwork for implementing cost-effective projects, providing new testing ground for biodiversity protection and restoration projects that store additional atmospheric carbon. This Technical Progress Report discusses preliminary results of the six specific tasks that The Nature Conservancy is undertaking to answer research needs while facilitating the development of real projects with measurable greenhouse gas reductions. The research described in this report occurred between April $1^{\text {st }}, 2005$ and June 30th, 2005. The specific tasks discussed include:
\end{abstract}

- Task 1: carbon inventory advancements

- Task 2: emerging technologies for remote sensing of terrestrial carbon

- Task 3: baseline method development

- Task 4: third-party technical advisory panel meetings

- Task 5: new project feasibility studies

- Task 6: development of new project software screening tool

Work is being carried out in Brazil, Belize, Chile, Peru and the USA. Partners include the Winrock International Institute for Agricultural Development, The Sampson Group, Programme for Belize, Society for Wildlife Conservation (SPVS), Universidad Austral de Chile, Michael Lefsky, Colorado State University, UC Berkeley, the Carnegie Institution of Washington, ProNaturaleza, Ohio State University, Stephen F. Austin University, Geographical Modeling Services, Inc., WestWater, Los Alamos National Laboratory, Century Ecosystem Services, Mirant Corporation, General Motors, American Electric Power, Salt River Project, Applied Energy Systems, KeySpan, NiSource, and PSEG. 


\section{TABLE OF CONTENTS}

Title Page..................................................................

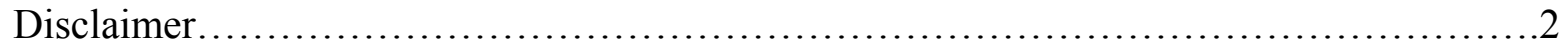

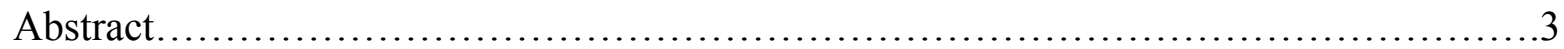

Table of Contents............................................................4

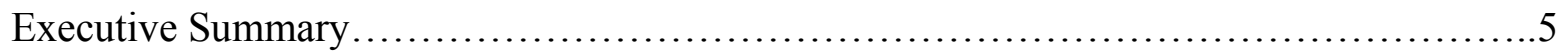

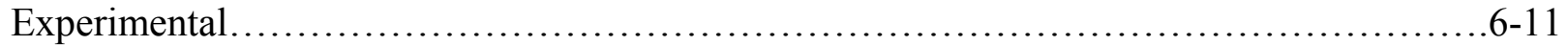

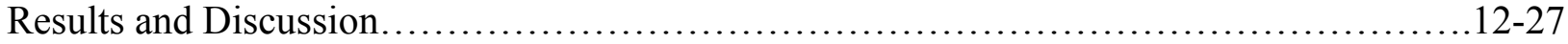

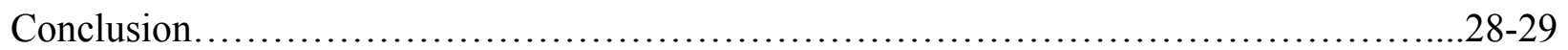

References..................................................................... 30 


\section{EXECUTIVE SUMMARY}

During the July to September quarter of 2005 considerable progress has been made on all aspects of this research project. A draft of the results of the carbon inventory work carried out over the last three years in the Atlantic Forest of Brazil has now been completed and sent to the Department of Energy for review and comments. Significant progress on the forest inventory work in Tahoe National Forest has also been made with a number of plots already sampled along the newly established transect.

The orthorectified QuickBird scenes for the Tahoe National Forest and the Garcia River forest have now been delivered. The topical report completed by Winrock International entitled "Application of Mutlispectral 3-Dimensional Aerial Digital Imagery for Estimating Carbon Stocks in a Bottomland Hardwood Forest" has now been completed and submitted. The completion of all the M3DADI studies by Winrock International and partners has allowed the remaining report " Cost Comparison of the M3DADI System and Conventional Field Methods for Monitoring Carbon Stocks in Forests" to be written. This report is still in draft version and is under review by The Nature Conservancy currently.

Research has carried on steadily to make progress and complete the baseline studies. The baseline study in northwest Florida was finished, and data analysis continues for the Chile and Peru work. Plans for the third-party technical advisory panel in early 2006 are being made. The focus of the meeting will be on methodologies needed to quantify land use and forestry offsets to qualify for different carbon markets and voluntary registration regimes. This topic will allow for consideration of the approaches we are taking within emerging climate mitigation regimes, to assess compatibility and make adjustments in approaches as appropriate.

The Feasibility study for longleaf pine Restoration in northwest Florida has been completed and submitted. Work on the Northeast Feasibility study has been underway. Neil Sampson has completed a draft of part 1 of the work which is under review by the project team. Work on part 2 is also progressing, with some data still being assembled for a completion of a first draft. Project team members also held a meeting in Connecticut with key stakeholder to brief them on the project. 


\section{EXPERIMENTAL}

\section{Task 1 Carbon Inventory Advancements}

Carbon Inventories can be increased and costs lowered through improved techniques. Forest Inventories have been carried out for a number of reasons; to use for M3DADI calibration (task 2), for use in carbon baseline development (task 3) and for development of new regression equations and improved estimates of biomass for different terrestrial systems. Some calibration of Laser Induced Breakdown Spectroscopy (LIBS) calibration has also been carried out using soils collected during TNC research in Indiana and in association with a workshop in Brazil.

\section{Task 2 Emerging technologies for remote sensing of terrestrial carbon}

Emerging remote sensing technologies, including high-resolution satellites such as QuickBird and Light Detection and Ranging (LIDAR), provide potential tools to scale up carbon estimates from hectare-scale forest inventory plots to landscapes of hundreds of square kilometers. We will test the capabilities of three technologies, QuickBird $0.6 \mathrm{~m}$ resolution imagery, LIDAR, and digital videography to quantify aboveground forest carbon at three sites in the United States.

We will employ QuickBird and LIDAR in an applied research project "Monitoring Forest Carbon and Impacts of Climate Change with Forest Inventories, High-Resolution Satellite Images, and LIDAR.” The project is a collaboration of the California Department of Parks and Recreation, Carnegie Institution of Washington, the Conservation Fund, Colorado State University, the Nature Conservancy, Stanford University, USDA Forest Service, U.S. Department of Energy, and the University of California, Berkeley.

Multispectral 3-D Aerial Digital Imagery (M3DADI) studies will be conducted by Winrock International. M3DADI uses GPS-base mosaicing techniques and off-the-shelf equipment with camera mounts that can be attached to any Cessna aircraft to generate accurate raster-based photomaps. After the videography is flown, 3-dimensional (3D) reconstruction are developed from video that identifies terrain features and vegetation types and measures the height and mass of individual trees. The measurements from the videography are then calibrated with the carbon inventory data and regression equations from Task 1 to estimate carbon remotely.

\section{Research in California: Monitoring Forest Carbon and Impacts of Climate Change with Forest Inventories, High-Resolution Satellite Images, and LIDAR}

We are establishing permanent forest inventory plots to provide independent estimates of species composition, tree sizes, and above-ground biomass and to furnish the data to assess the accuracy of QuickBird-derived crown diameter and LIDAR-derived tree height and crown diameter. In the Tahoe National Forest, we used a $1.25 \mathrm{~km}$ resolution grid to establish a systematic sample of 36 plots using the USDA Forest Service Forest Inventory and Analysis (FIA) design. In the Garcia River forest and the Mailliard Redwoods State Reserve, we used the California Department of Forestry and Fires Protection vegetation map to establish a sample of 40 FIA plots stratified by trunk diameter. In the FIA plots, the inventory team is identifying the species of every live tree 
of diameter $\geq 20 \mathrm{~cm}$ at a height of $1.37 \mathrm{~m}$, tagging each tree, and measuring the height, trunk diameter, and crown diameter. In addition, the inventory team is measuring a sub-sample of small trees, dead wood, and litter and estimates one, ten, and 100 hour fire fuel loads.

Using species-specific allometric equations of biomass as a function of trunk diameter, we will directly calculate aboveground biomass for each analysis area. In addition, we will develop equations of trunk diameter as a function of height and crown diameter together and as a function of crown diameter alone in order to calculate biomass from LIDAR and QuickBird data.

For the Sierra Nevada transect, the inventory team is establishing eight sets of four permanent 20 $\mathrm{m} \times 50 \mathrm{~m}$ Whittaker plots in late seral stands with a southwest aspect at approximately $200 \mathrm{~m}$ elevation intervals. We selected areas with no significant timber, livestock grazing, or fire management history. In each Whittaker plot, the team is identifying the species of and measuring the height and trunk diameter of every tree of diameter $\geq 20 \mathrm{~cm}$ at a height of $1.37 \mathrm{~m}$. In addition, the inventory team is measuring a sub-sample of small trees, dead wood, and litter and estimates one, ten, and 100 hour fire fuel loads. We also plan to take cores of a sample of trees to estimate ages and growth rates of measured trees.

LIDAR is an airborne laser system that can measure the height of individual trees and produce a three-dimensional profile of the interior of a forest canopy. The basic measurement that a LIDAR device makes is the distance between the sensor and a target, derived from the time that elapses between the emission of a laser pulse towards the target and the return of the pulse's reflection to the sensor. Equipped with global positioning system (GPS) receivers and inertial navigation systems, LIDAR devices make georeferenced digital elevation measurements at discrete sample points along a flight path. Merging of point samples from a series of flights generates a single spatial data layer. We are employing a discrete LIDAR system that records the intensities of first and last return while an integrated differential global positioning system (GPS) receiver establishes the coordinates of the detector. The system creates digital elevation data layers for the ground surface and the canopy.

The LIDAR spatial resolution of $1 \mathrm{~m}$ is finer than the size of many trees, so we will process LIDAR data to give multiple indices of canopy height within raster cells with a spatial resolution of $15 \mathrm{~m}$, the diameter of an FIA annular plot. We will then develop regression equations of LIDAR-derived height indices at $15 \mathrm{~m}$ spatial resolution to the aboveground carbon calculated in the forest inventory plots. Application of the regression equation to non-inventoried areas will allow calculation of aboveground carbon per unit area.

We will also use an alternate method of calculating aboveground carbon from LIDAR data by delineating individual tree crowns and calculating crown diameter and height of individual trees. The inventory-derived equations of trunk diameter as a function of crown diameter and height will allow us to estimate the biomass of each tree and calculate aboveground carbon per unit area. We will also compare LIDAR height and crown estimates with forest inventory measurements and test the ability of LIDAR-derived crown estimates to improve estimates of trunk diameter. 
The QuickBird satellite captures photographic-quality images (Figure 1) at $0.6 \mathrm{~m}$ panchromatic resolution and $2.4 \mathrm{~m}$ multi-spectral resolution in five spectral bands of 11 bit data depth.

QuickBird captures data across a swath of $16.5 \mathrm{~km}$ on the ground. The satellite circles the Earth every 94 minutes at an altitude of $450 \mathrm{~km}$, in a sun-synchronous orbit with the descending node crossing the Equator at approximately 10:30 AM local solar time. The owner of QuickBird, DigitalGlobe, Inc., allows users to purchase data at times and locations specified by the user.

We are using orthorectified QuickBird scenes with a geographic location root mean square error of $6.2 \mathrm{~m}$. We are developing automated programs that combine iterative local maxima and minima filtering with analysis of extracted ordinate data to detect crown perimeters and crown diameters. We will compare these crown estimates with forest inventory crown measurements. The inventory-derived equations of trunk diameter as a function of crown diameter will allow us to estimate the biomass of each tree and calculate aboveground carbon per unit area. The QuickBird spatial resolution of $0.6 \mathrm{~m}$ is finer than the size of many trees, so we will calculate the aboveground carbon density at a resolution of $15 \mathrm{~m}$, the diameter of the FIA annular plot.

\section{Task 3 Carbon Baseline Method Development}

We will develop and refine spatially explicit methods for estimating the carbon sequestration baseline for proposed forest conservation and reforestation projects at three sites in the United States and five sites in Latin America. The methods project possible future deforestation and reforestation trends and permit the calculation of carbon offsets from project activities.

Baseline work in Chile We are using the following data from previous work:

1. Allometric equations, temperate rainforest, Chile

2. Above- and belowground biomass in forest, woodland, and grassland, Decima Región, Chile

3. Land cover, Valdivia and Osorno Provinces, 1986, 1999

4. Projection of forest cover, five comunas, 2012

We are using the previous data and new data to conduct a Forest Restoration Carbon Analysis (FRCA) along the following steps:

1. Acquire Landsat scene for Path 233, Row 88 for February 1, 2002

2. Geographically register 2002 scene to the registered 1986 scene.

3. Delineate the ecological boundary of coastal temperate rainforest (bosque humido templado de la cordillera de la costa) using national land cover data. The area of analysis will be the section of coastal temperate rainforest between the Rio Calle Calle and the Rio Huevelhue.

4. Combine detailed forest types into a set of forest classes of similar ecology, botany, and biomass.

5. Conduct supervised classification of Landsat scenes into the defined forest classes.

6. Estimate 1988-2004 changes in forest cover and carbon

7. Develop biomass growth curves

8. Compile deforestation and reforestation factors:

a. distance to non-forest

b. distance to forest 
c. land ownership (empresa $=1$, non-empresa $=0$ )

d. distance to roads

e. distance to rivers

f. distance to population centers

g. elevation

h. slope

i. aspect

9. Conduct principal components analyses to determine weight of factors

10. Develop equations of deforestation and reforestation vs. factors

11. Calculate probability of deforestation and reforestation

12. Project future native forest cover

13. Estimate carbon storage due to proposed project

Baseline work in Peru The team from ProNaturaleza is measuring the diameter at a height of $1.3 \mathrm{~m}$ of all trees of in the plots where this diameter is greater than or equal to $10 \mathrm{~cm}$. The team is identifying each measured tree to the lowest possible taxonomic level. The team is tagging each measured tree with an aluminum tags at a height of $1.4 \mathrm{~m}$.

\section{Task 4 Third-Party Technical Advisory Panel Meetings}

Standardizing measurement procedures and methods for carbon monitoring is a major step in the demonstration that land use projects should be creditable under any future regulatory mechanism. The Technical Advisory Panel (TAP) will gather a group of experts to evaluate existing methods and to develop standardized carbon offset measurement guidelines for use in all land-use change and forestry projects.

\section{Task 5 New Project Feasibility Study}

While there seem to be a variety of project ideas that would lead to cost-effective sequestration and biodiversity projection, there has been little work accomplished to explore the feasibility of these ideas. Within the United States, we have yet to develop sound knowledge of the potential for implementing specific forestry and agricultural carbon sequestration projects. By assessing the cost and potential carbon benefits of different domestic projects we can learn more about how conservation and carbon sequestration projects may or may not be compatible.

The work proposed to be carried out in the Northeast region, seeks to provide:

- Historical trend of sinks and sources for carbon emissions and/or sequestration in the landuse and forestry sector for the period about 1987-1997;

- Classification of the land conservation and management activities that represent the major opportunities for carbon storage on the land for each state by county within the Northeastern U.S.;

- Improved data on the quantity and costs of carbon storage for major classes of land-use and forest-based projects in the Northeast in a format that allows comparison with opportunities in other regions; 
- Greater confidence within the Northeast region on how land-use and forestry projects that reduce emissions or sequester carbon can fit into State energy and natural resource planning goals; and

- Potential environmental co-benefits from carrying out the projects that reduce emissions or sequester carbon.

The following are goals for each section of this project.

\section{Stakeholder Outreach and Input}

The goal under this task is to involve and invite input from various stakeholders including state regulatory land use and natural resources staff in the Northeast states, non governmental organizations (NGOs), and industry representatives throughout the project. The Team will seek their input and feedback as to our scope of work, the datasets to be used, assumptions regarding implementation of land use changes, and the methodology for determining carbon creation potential and costs.

Identify and estimate carbon sources and sinks in the Northeast region.

The goal for this phase is to identify and quantify the key sources and sinks of carbon in the land-use and forestry sector of the Northeast region at the county level, for the period of about $1987-1997^{1}$ (in other words measure the carbon emission or sink trend over the most recent decade of data available.)

\section{Classify the Carbon Storage Opportunities}

The goal is to identify the existing classes of lands in the region and then to identify a suite of land use changes that could take place to increase carbon sequestration.

\section{Quantify the carbon benefit}

The goal is to quantify the costs of changing the use of land for carbon sequestration, including opportunity costs, conversion costs, maintenance costs, and measuring and monitoring costs.

\section{Identify Environmental Co-Benefits from Changes in Land Use}

The Team's goal is to identify the potential environmental and economic co-benefits of implementing certain land-use change activities and to map these benefits along with the carbon supply and cost curves.

\section{Summary Maps and Report}

Finally, the Team will prepare county scale summary maps of quantities of carbon and their associated costs for the major classes of potential land-use and forest-based activities in the Northeast region in a format that allows comparison with opportunities in other regions in the U.S. The Team will work to produce a written report containing summarizing the background, methodology, findings, and recommendations of the study.

\section{Task 6 Development of new project software screening tool}

\footnotetext{
${ }^{1}$ If we can get the 2002 NRI data broken down by county, we plan on using that data instead of the 1997 data.
} 
Carbon measurement and monitoring costs are unique transaction costs for forest-based carbon sequestration projects. Project developers need to weigh the costs of carbon measurement and monitoring against the potential benefits of the sale of carbon offsets (carbon revenue). Carbon benefit data from USDA Forest Service inventories will be combined with carbon measurement and monitoring variables in a spreadsheet-based tool to allow users to compare potential carbon costs and revenues on a project level. 


\section{RESULTS AND DISCUSSION}

\section{Task 1: Carbon Inventory Advancements}

\section{Brazil}

The final report written by SPVS (Sociedade de Pesquisa em Vida Selvagem e Educação Ambiental) and The Nature Conservancy Brazil covering carbon inventories in the Atlantic Forest of Brazil has now been submitted to John Litynski for comments.

\section{California}

The forest inventory team completed inventories of all 36 forest carbon plots in the Tahoe National Forest and 4 out of 8 sets of Whittaker plots along the Tahoe transect.

( See Figures 1 and 2) 


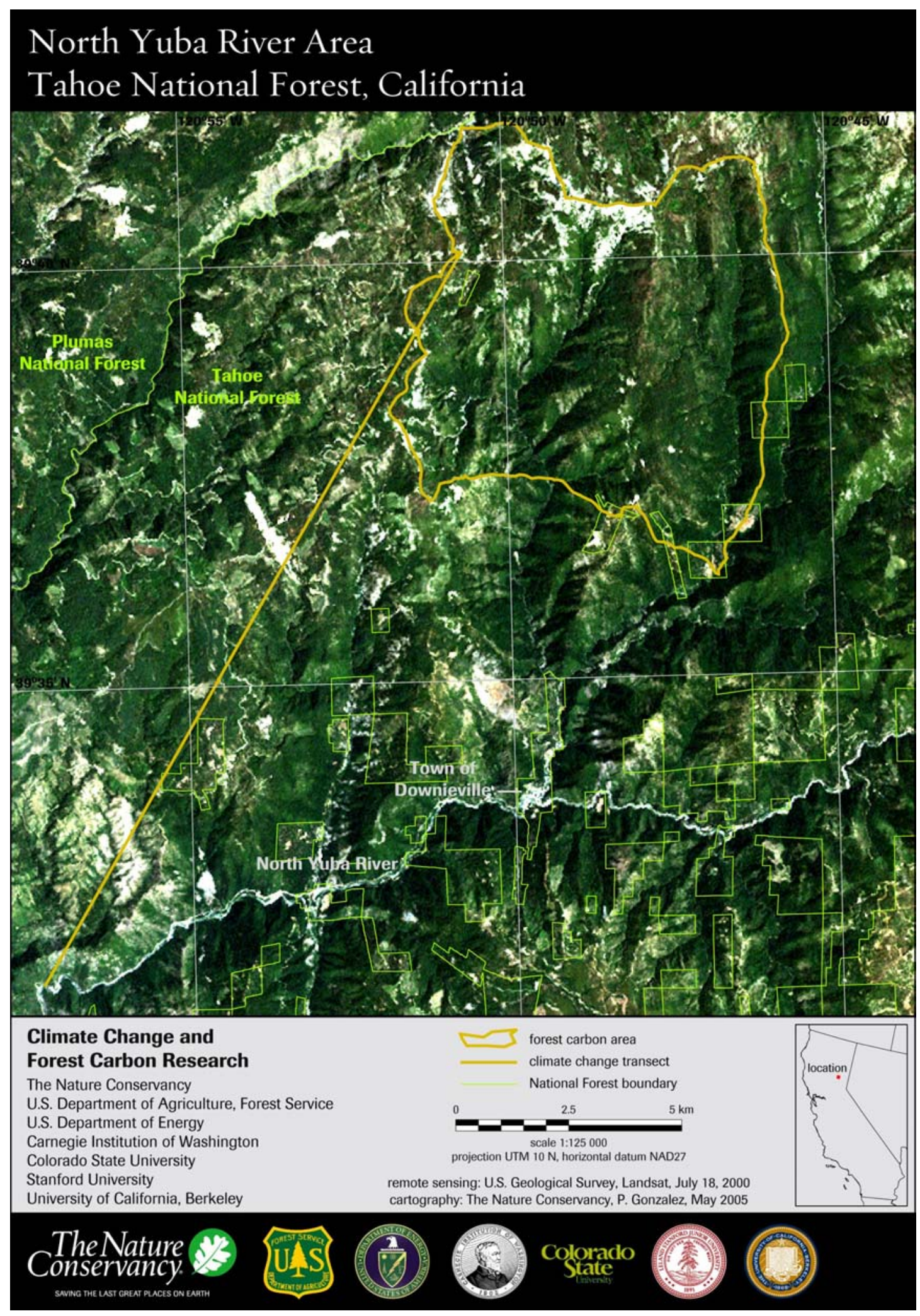

Figure 1: North Yuba River Area, Tahoe Forest, California 


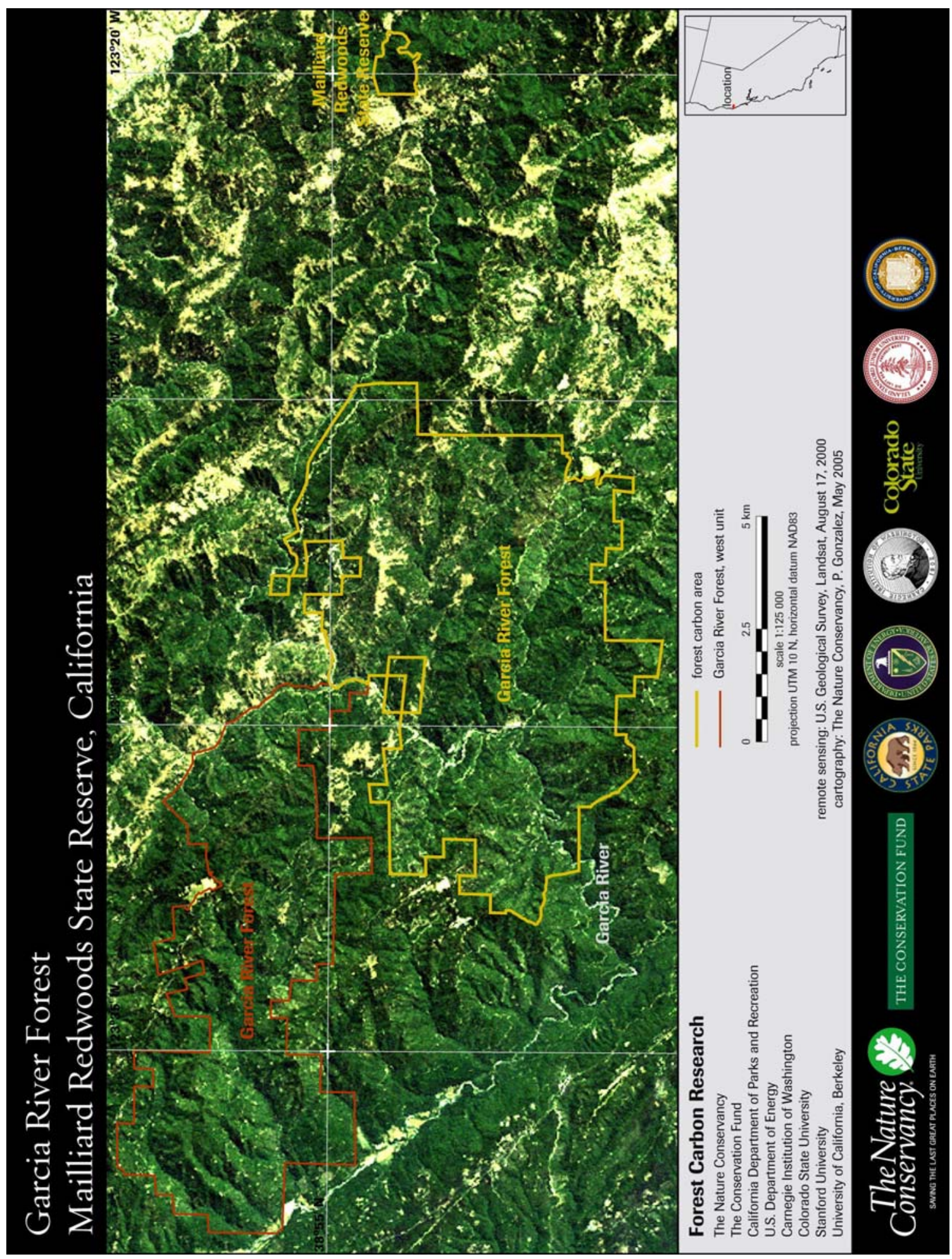

Figure 2: Garcia River Forest, Mailliard Redwoods State Reserve, California 


\section{Task 2: Remote Sensing for Carbon Analysis}

\section{$\underline{\text { California }}$}

DigitalGlobe, Inc. delivered to us orthorectified QuickBird scenes acquired August 2, 2005 over the Tahoe National Forest and August 7, 2005 over Garcia River forest and Mailliard Redwoods State Reserve. Finally, Sanborn Map Company flew 6 days of LIDAR missions and completed acquisition of LIDAR data at all research sites. They used an Optech ALTM 2050 sensor with the following characteristics:

Scan Width (Half Angle) $\quad 20^{\circ}$

Scan Frequency $38 \mathrm{~Hz}$

Laser Repetition $50000 \mathrm{~Hz}$

Flying Height $\quad 800 \mathrm{~m}$

Aircraft Speed $\quad 260 \mathrm{~km} \mathrm{~h}^{-1}$

Line Overlap $\quad 31 \%$ (160 meters)

Swath Width $\quad 580 \mathrm{~m}$

Line Spacing $\quad 400 \mathrm{~m}$

Data Posting $\quad 1 \mathrm{~m}$

The research team is analyzing all of this data.

In addition, the USDA Forest Service and the Nature Conservancy hosted local journalists at the headquarters of the Tahoe National Forest for a news conference given by Patrick Gonzalez. The Union Newspaper (Grass Valley, CA) and the local web site <www.yubanet.com $>$ featured articles about the research the next day. In Sacramento, CA, Patrick presented a poster on the research at the Second Annual Climate Change Research Conference and First Scientific Conference of the West Coast Governors' Global Warming Initiative.

\section{Cost Comparison report:}

A draft of the topical report "Cost Comparison of the M3DADI System and Conventional Field Methods for Monitoring Carbon Stocks in Forests" was completed by Winrock International and submitted to The Nature Conservancy for review. The executive summary is below:

\section{Executive Summary}

\section{Cost Comparison of the M3DADI System and Conventional Field Methods for Monitoring} Carbon Stocks in Forests

Given the interest in implementing land-use change and forestry projects for mitigating carbon dioxide emissions, there is potentially a large demand for a system to measure carbon stocks accurately and precisely in a cost-effective manner. To date most methods for measuring carbon stocks in forests accurately and to targeted levels of precision rely of standard field methods. Although the use of standard field techniques is not an expensive operation per se $(\$ 4-8 /$ ha for a 1,000 ha tract of land; Mooney et al., 2004), given the potentially large number of forest-based activities that could be implemented in the US, any savings in cost of measuring and monitoring carbon in forests would be advantageous to all stakeholders. 
A potential way of reducing costs of measuring the carbon stocks of forests is to collect the key data remotely. Winrock team has designed such a system (a multispectral three-dimensional aerial digital imagery system-M3DADI) that collects high-resolution overlapping stereo imagery ( $\leq 10 \mathrm{~cm}$ pixels) from which we can distinguish individual trees or shrubs. The M3DADI system has been applied to a pine savanna in Belize, a tropical broadleaf forest in Belize, and temperate bottomland forest in the Delta National Forest, US. In each of these settings, the carbon stocks in trees were measured using both the M3DADI system and conventional field approaches. In this report, we report on the comparison of the costs for monitoring these forests using the M3DADI and field approaches. We collected data only for the time (in person-hours) involved in each of the various steps in preparing, acquiring, interpreting, and entering the data into spreadsheets for the final step in the analysis. The overall goal of this task is to compare the total person-hours needed for both approaches at the three sites to collect the same set of data to achieve a $95 \%$ confidence interval (CI) of $\pm 8 \%$ of the mean based on the sampling error only.

In all three study sites, the time cost for the field approach is about 2.5 to 3.5 times longer than for the M3DADI approach to achieve the same precision level. The overall time involved in the data-collection preparation phase using the M3DADI approach represented a larger percent of the total time (20-80\% of the total time) than the field approach (about $5 \%$ or less of the total time). The main reasons for the difference in time costs for the measurements of the plots are: the shorter time needed to measure an image plot versus a field plot and the lower coefficient of variation in carbon stocks among image plots versus field plots, resulting in fewer plots needed for the M3DADI approach to achieve a given precision target.

The image plots are presently interpreted and measured manually — a relatively time consuming step in the process. However, due to the recent advances in high-resolution imagery and sophisticated software, automating these processes may be possible. After reviewing the recent literature and testing four of the commercially available products, we conclude that the existing software products are unable to automatically delineate tree crowns and heights in these forest types.

\section{Delta National Forest:}

The final version of the Delta National Forest topical report was submitted to John Litynski. This report was written by Winrock International and reviewed by staff in the Global Climate Change Initiative at The Nature Conservancy. The title and executive summary are pasted below:

\section{Executive Summary}

\section{Application of Multispectral 3-Dimensional Aerial Digital Imagery for Estimating Carbon} Stocks in a Bottomland Hardwood Forest

The purpose of this study was to determine the ability of Winrock's aerial imagery system (Multispectral Three-Dimensional Aerial Digital Imagery -M3DADI) to accurately and precisely sample biomass carbon in a homogeneous closed crown system such as Delta National Forest. 
From 30 aerial imagery plots we estimated an aboveground live biomass carbon value of $100.4 \mathrm{t}$ $\mathrm{C} /$ ha \pm 6.7 (mean $\pm 95 \%$ confidence interval). The $95 \%$ confidence interval from these measurements represents just $6.7 \%$ of the mean.

Previous field measurements in Delta National Forest determined an aboveground live biomass carbon estimate of $114.9 \mathrm{t} \mathrm{C} / \mathrm{ha} \pm 15.8$. The range of values from the 23 measured field plots was $34-174 \mathrm{t} \mathrm{C} / \mathrm{ha}$. The range from the aerial plots was $61-127 \mathrm{t} \mathrm{C} / \mathrm{ha}$.

From the variance of the estimates it was determined that 39 plots would be required to achieve a $95 \%$ confidence interval equal to $10 \%$ of the mean if measurements were on the ground. From

aerial measurements just 13 plots would be required. The terrain in Delta National Forest is very hard to traverse with flooded swamps and sloughs. The advantages of aerial measurement are therefore immediately apparent.

Biomass carbon estimates from the aerial data were derived using biomass regressions to crown area. Height was not used in the regressions due to a difficulty in determining ground height through the homogeneously closed canopy. Straight-line relationships were used as the homogeneous crown created the potential for high rates of error in delineating individual crowns. We determined here that in a broadleaf forest such as exists in Delta NF, calculating crown area from the area of an ellipse (determined through measuring two crown diameters) led to an $8 \%$ overestimation. As the biomass regression equations were derived in this manner we created a correction factor to remove this source of error.

\section{Task 3: Baseline Method Development}

\section{Chile Baseline Study}

We have purchased the February 1, 2002 Landsat scene from USGS. The Universidad Austral de Chile team has registered the scene to the 1988 image and is conducting a supervised classification. We expect the following results of this work in the future:

1. Geo-registered 1988 and 2004 Landsat scenes (GeoTiff files)

2. Boundary of coastal temperate rainforest (ArcGIS shape file)

3. Forest cover 1988 and 2004 (GeoTiff files)

4. Forest cover change 1988-2004 (GeoTiff file)

5. Biomass growth curves (Excel file)

6. Factor vs. deforestation and factor vs. reforestation curves (Excel file)

7. Factor weights from principal components analysis (Excel file)

8. Future probability of deforestation (GeoTiff file)

9. Future probability of reforestation (GeoTiff file)

10. Projected 2020 native forest cover (GeoTiff file)

11. Projected 2004-2020 forest cover change (GeoTiff file)

12. Projected carbon baseline of Reserva Costera Valdiviana (Excel file) 
13. Projected carbon sequestration of avoided deforestation and of forest restoration in the Reserva Costera Valdiviana (Excel file)

14. FRCA results (version in English and version en Español)

\section{Peru: Selva Central Baseline Study}

ProNaturaleza has completed work on 12 out of 21 permanent inventory plots in secondary and primary forest areas.

\section{Florida Baseline Study}

The Florida baseline study carried out in the northwest of the state has now been completed, and submitted as a topical report to John Litynski. Below is a summary of the findings:

\section{$\underline{\text { Summary - Evergreen Timberland in northwest Florida baseline study }}$}

The study area was set to 3 counties in the Florida Panhandle. These counties represent the areas visited by Winrock personnel and are typical of the Gulf Coast Plain Ecosystem. The counties of interest are Escambia, Okaloosa, and Santa Rosa.

A Landsat 7 image from 01-25-2001 was classified using the maximum likelihood method into 6 land cover categories, evergreen, transitional, residential, water, wetland, and other. The other category included all other types of land cover including other types of forests, bare soils, agriculture and grasses.

Maximum likelihood is the most common classification method used by remote sensing professionals. It is a full multidimensional probability function based on Bayesian theory. $A$ posterior probability is calculated for each pixel by using the mean and variance/covariance from a set of definition files, referred to as training sites. This probability is then used to assign each pixel to the most likely class. In this case, the training sites were areas visited by David Shoch and Sean Grimland in December 2004. In the maximum likelihood technique, the training sites must be assigned prior probabilities. For this analysis, all training sites were assigned equal prior probabilities with which each pixel can be classified into a land cover category.

NLCD (National Land Cover Data) is a 21-category land cover classification scheme with a spatial resolution of 30 meters that has been applied consistently over the conterminous U.S. It is based primarily on the classification of Landsat 5 TM (Thematic Mapper) 1992 imagery. Landsat 7 was launched in 1999 and is a joint initiative of the U.S. Geological Survey (USGS) and the National Aeronautics and Space Administration (NASA). The objective of the Landsat Project is to ensure the collection of consistently calibrated 30 meter spatial resolution imagery of Earth and to ensure the data are of maximum utility in supporting the monitoring of changes in the Earth's land surface. NLCD categories were combined to facilitate comparison with the classified Landsat 7 image.

The study area contained 15 NLCD categories which were reclassified into the same 6 land cover categories as the Landsat 7 image in order to make a comparison. The area of evergreen 
forest in the NLCD was 229,695 hectares, compared to the 190,932 hectares of evergreen forest in the interpreted Landsat 7 image. This disparity is equal to a loss of 38,763 hectares or an annual rate of loss of 4,307 hectares (10,638 acres) for the 9-year period for these 3 Florida counties.

\section{Task 4: Third-party technical advisory panel meeting}

The next Technical Advisory Panel meeting is planned for early 2006. A summary of the objectives and subject area are as follows:

\section{Objective:}

Discuss the practicalities of developing land based carbon offset projects to meet credit certification under different US based and international regimes/markets. Review the methodologies currently being developed or applied for baseline and monitoring, as well as logistics of achieving certification, and project start-up and implementation.

This years Technical Advisory Panel (TAP) meeting will focus on methodologies needed to quantify land use and forestry offsets to qualify for different carbon markets and voluntary registration regimes.

Currently there is considerable discussion and interest as to what approved "Clean Development Mechanism" (CDM) baseline and monitoring methodologies will contain. To date no proposed projects have been granted approval by the CDM Executive Board (EB), who reviews project proposals. CDM approval allows developing countries to sell their credits to assist developed nations in meeting their Kyoto agreed commitments.

The 1605 (b) "voluntary greenhouse gas reporting program" was established in the United States in 1994 and run by the Department of Energy. Over the past two years the reporting rules have been reviewed, along with the technical guidelines for so doing. The amended rules will come into affect in the fall of 2005, with implications for reporting voluntary offset credits from land use and forestry activities.

The United States now also has a number of voluntary carbon markets in operation, namely the California Climate Action Network (CCAR), Chicago Climate Exchange (CCX) and the Oregon Climate Trust (OCT).All have specific rules for quantifying, registering and monitoring land base offsets. The Northeastern States are also developing the "Regional Greenhouse Gas Initiative" (RGGI) whereby states will set a carbon emissions CAP. It is hoped RGGI will include a provision to meet the CAP through forestry and land based offsets. In addition the Climate, Community and Biodiversity Alliance (CCBA) has developed best practice standards in developing land based offset projects.

This Technical Advisory Panel will cover the practicalities of baseline development, carbon stock and accumulation estimation and monitoring methodologies needed to comply with the various requirements set out by the different regimes described above. Examples will draw on research carried out under the Department of Energy grant and research carried out by other 
organizations. Costs of using different approaches will be also be considered, as will fundraising for project initiation.

\section{Task 5 New Project Feasibility Studies}

\section{Stakeholder Outreach and Input}

\section{Ongoing stakeholder outreach -}

The Nature Conservancy recently launched a new tool on the internet site, Conserveonline, meant to share project information with team members as well as with a broader stakeholder audience. Documents can be shared privately among team members or be made public and shared with all stakeholders related to the project. The web site address is:

http://conserveonline.org/workspaces/. Information has been posted on this site under Workspace name, Northeast Carbon Feasibility Project. Anyone can now access the site to download information about the project. We will be sending out a notice to all stakeholders shortly to notify them of this site and the ability to access project information. As we proceed with the project, we will use this site to post sections of the report as they are completed.

Team members Neil Sampson, Sandra Brown and Sarah Murdock attended a meeting in Connecticut on 9/29/05, with Connecticut Public officials and Nature Conservancy staff to brief them on the project. Team members presented an overview and details about the project similar to what was presented in the previous stakeholder meetings. In attendance were, Chris Nelson of Connecticut Department of Environmental Protection, Air Division; Daniel Leff, Deputy Commissioner of Natural Resources Div.; Donald Smith, State Forester; Jeff Ward, Connecticut Ag. Extension Station; Lise Hanners, Connecticut Dir. of the Nature Conservancy; David Sutherland, Government Relations, The Nature Conservancy; and Mark Carbetta, Director of Conservation, The Nature Conservancy. We responded to questions and comments. The Connecticut public officials commented that afforestation will likely not present much if any opportunity in Connecticut. The Connecticut officials seemed to be interested in using the project results to promoting programs and efforts in Connecticut that promote multiple environmental benefits including carbon sequestration.

\section{Identify and estimate carbon sources and sinks in the Northeast region.}

Work on Part II is well underway, with an analysis of the recent trends in Northeast carbon sources and sinks as they relate to terrestrial ecosystems. There are some data still needing to be assembled. The USDA Forest Service has indicated a willingness to share their data on the county-level forest carbon changes in the last two Forest Inventory and Assessment (FIA) cycles. That data should be made available to the team in the coming week or two, and should provide an excellent basis for that aspect of the analysis.

We are also in the process of downloading all of the basic county data for 1990, 2000, and 2004 from the Conservation Technology Information Center (CTIC). Those data, generally available only to the paying members of CTIC or to others at a significant fee, are being provided courtesy of John Hassell, CTIC Director, to whom we are grateful. Once the data are downloaded and restructured into spreadsheet formats, we will seek to draw interesting conclusions about recent trends in agricultural practices in the region. 
We have carried out several analyses of the 1997 National Resources Inventory (NRI) data that have relevance to changes in cultivation practices, cultivation of organic soils, and land use change in the period 1987 to 1997 . We are in communication with the Natural Resources Conservation Service (NRCS) specialists to see what, if anything, we can get from the more recent (NRI) efforts that will enable us to include more recent information in our analyses, but as yet have no firm decisions.

The most important aspect of land-use change in the Northeast may be the most difficult to analyze in terms of carbon sources and sinks, given the existing data and state of the research. Both agricultural land and forests are being converted to all forms of rural and urban development in the region, and these changes have important implications for both recent and future sources and sinks of carbon from these systems.

What is lacking, however, is an adequate characterization of these developments from which to derive an estimate of carbon sinks and sources. For example, a development that converts cultivated cropland to a subdivision that features homes, roads, grass and urban trees can reduce carbon emissions from the cultivation and increase sequestration through lawns and urban trees. Another development of equal size that is converted into a shopping center and paved parking may effectively entomb soil carbon and reduce annual fluxes to near-zero. One that began as a 100 year-old forest that was subdivided into 5- or 10-acre lots, with small roads and homes, might retain most of the trees and have limited impact on carbon sinks and sources. Another of the same size that was cleared, burned, and turned into a compact subdivision or mall would have a significant carbon emission and very little chance of future sequestration.

The problem with the data available is that while we can tell what the land use and cover was in 1987, we have very little information about the nature of the development that was recorded in 1997. As a result, we will have to make and test some assumptions about the potential carbon impact, with very little research for guidance. We are aware of some current research in the Northeast to attempt a carbon analysis of selected developments, but the results won't be available for some time, it appears. Hopefully, our work (and its review by experts in the region) will produce some additional insights into what is a very important land use dynamic in the region.

The next quarter's work will be focused on finishing both Parts I and II in format for stakeholder review, and providing necessary data and input into the work on Part III of the report. We anticipate having an initial draft of Part II ready for the project team's review by mid-November. While this is somewhat behind our original schedule, the emergence of these latest data sets should provide a higher-quality analysis than if we had gone ahead earlier without them.

\section{Classify the Carbon Storage Opportunities}

In starting the work on Part 3 of the report, the Winrock International team has been analyzing the effectiveness of using various databases. 
GIS specialist Sean Grimland of Winrock explored the new National Land Cover Database (NLCD) database, and he determined that updates have not progressed far enough and thus the previous 1992 version will be used for this analysis.

In terms of soil maps, Winrock has decided to use the State Soil Geographic (STATSGO) database which is produced by generalizing the detailed soil survey data. The mapping scale for STATSGO is 1:250,000. The level of mapping is designed to be used for broad planning and management uses covering state, regional, and multi-state areas. Winrock has decided to opt to use STATSGO. Winrock also analyzed the use of the Soil Survey Geographic (SSURGO) database as it has a finer resolution (SSURGO resolution generally range from $1: 12,000$ to $1: 63,360)$. for this project and decided to use STATSGO because it is more complete for the Northeast region, although is a coarser resolution.

\section{Identify the existing classes of lands in the region. The classes of land will likely include croplands, grazing lands, forested lands, and developed lands.}

The Sampson Group has completed the working draft of Part I and it is currently being reviewed within the project team. The team review should be concluded in two weeks, and after the team's comments have been incorporated, we plan to make the draft available to the stakeholders for further review and comment.

Due to the size of these individual parts of the report, our current plan is to present each part as a separate downloadable file for these initial reviews. At the conclusion of the project, we will edit all the parts so that they flow together for a coherent full report.

Part I of the report briefly characterizes the Northeast Region to establish the basis for assessing terrestrial carbon sequestration opportunities in the region. The outline of the paper (17 pages without maps for the project team review) is:

Background for Part I

Overview

Population

Geography and Climate

Land Ownership and Use

Forests

Wetlands

Agriculture

Land Use Change

Summary

References

Part I captures and illustrates data sets that will be useful in the later Parts as work to assess carbon sequestration opportunities proceeds. The focus is on the agricultural and forest lands that are owned and managed by non-federal entities. The lands managed under federal and state mandates, where carbon sequestration policies are not likely to alter legislated management systems, were identified so that they could be screened out of subsequent analyses. This will 
make this product different than the estimates of total forest carbon sequestration produced by the USDA, which takes all forests, on all lands, into account as part of national carbon reporting.

The draft report of Part I contains 14 maps that portray regional characteristics. They are:

1. Location map

2. 2000 population density map. Produced from LandScan, a global map of population density produced at 1/2" x 1/2" scale by Oak Ridge National Laboratory for the Departments of Energy and Defense.

3. 2000 nightlights map. Produced by NASA.

4. 2000 population density by county, produced from U.S. Census data

5. Population change, 1980-2000, by county, produced from Census data.

6. Digital elevation map, from the National Map

7. Regional precipitation map, from the National Map

8. Bailey's Ecoregion Provinces, from the National Map

9. Regional land cover data, from the National Land Cover Data (USGS 1990's)

10. Federal and State Lands, from a variety of State and Federal sources to achieve an up-todate status where possible.

11. Percent forest cover of non-federal lands, by county, from the 1997 NRI data.

12. Forest cover types, from U.S. Forest Service, 2002

13. Percent cropland, by county, from the 1997 NRI data.

14. Change in non-working lands, 1987-1997, by county, from the 1997 NRI data.

All data sets for the maps are in standard ArcMap shapefile format and are portrayed in Albers Equal-area projection. Most are based on public data, as noted above, that were downloaded directly from federal sources. One exception is the 1997 NRI data, which are available in digital format for 1982, 1987, 1992, and 1997. These data were in raw file format, by state. We used Microsoft Access to assemble the state files into a regional data set and built the necessary queries to construct the needed data sets for evaluation in Microsoft Excel and ArcView 9.0.

The draft report contains 15 tables, as follows:

Table 1. Total, urban, and rural population by state, 2000

Table 2. Population change, 1980 to 2000, by state. Source: U.S. Census Bureau

Table 3. Population change, 1980-2000 and increase in non-working land, 1982-1997, by county.

Table 4. 1997 Land Use, by State and land use, in thousands of acres

Table 5. Forest area in the Northeast, by State, 1630, 1907, 1987, and 2002

Table 6. Forest type of forests established between 1987 and 1997, Northeast

Table 7. Forest stocking class, all species, by state.

Table 8. Forest ownership, by state, 2002

Table 9. Net annual growth, removals, and mortality of growing stock on timberland by species group and State, 1996, Northeast

Table 10. Estimated wetlands losses, 1790-1980, Northeast, in acres, by state

Table 11. Cropland Change, 1982 to 1997, by state

Table 12. Change in number of milk cows and total milk production, Northeast, 1993-2002, by state 
Table 13. Tillage practices, 2000 crop year, Northeast, by crop grown

Table 14. Increase in developed land, by state, 1982-1997

Table 15. Land use in 1997 compared to land use in 1987, Northeast Region

All tables are prepared in Microsoft Excel and the basic data are available for downloading and review. The draft report also contains 4 figures, as follows:

Figure 1. Increase in lot size per house in recent years. Data from the National Housing Survey, National, not geographically available at state or regional level

Figure 2. Forestland ownership, Northeast, 2002. Source: USDA Forest Service 2003

Figure 3. Crop types grown, 1987 and 1997, Northeast. Source: USDA 2001

Figure 4. Impact of land use change on forests, 1987-1997, Northeast, showing non-forest land use affected. Source: USDA 2001

It is likely that the project team review will reveal some needed changes in these maps, tables, and figures, so the subsequent draft of Part I may contain somewhat different elements than listed above. It is also possible that work on the other Parts of the report will develop data or insights that are most logically presented in Part I. If that occurs, we will incorporate all those changes in the final editing of the report.

\section{Longleaf Pine Restoration in Northwest Florida}

Winrock International revised the report based on comments from Conservancy staff and John Litynski. The report was clarified to reflect the focus on lands in Northwest Florida, prices of carbon dioxide equivalent were applied, and carbon stored in timber products was incorporated throughout. Conservancy staff reviewed and approved the revised report and submitted the report to John Litynski in September.

The executive summary of the final report is below:

\section{Executive Summary: An Assessment of Carbon Sequestration Potential of Longleaf Pine Restoration on Existing Production Timberland in Northwest Florida}

To reverse the losses of longleaf pine forests in the southeastern USA, the potential for financing longleaf pine restoration with carbon payments was examined. Such a study requires data on current and potential future land uses in combination with the carbon stocks under each of the land uses. The goals of this study were:

- Examine the extent and direction of recent changes in timberland in northwest Florida and the availability of land for restoration projects.

- Estimate the change in carbon stocks resulting from different approaches to reforesting with longleaf pine in northwest Florida through conversion of a slash pine plantation with different expected future land uses. Carbon data were obtained from the literature and from field measurements made in northwest Florida. 
The dominant trend in change in ownership of US forestlands is from industrial management to TIMOs (Timberland Investment Management Organizations). Estimates suggest as much as 1215 million acres of industrial timberland in the US will be transferred out of industry ownership in the next decade. However, this ownership change is not accompanied by any significant change in carbon stocks. Carbon benefits arise where forest clearance is prevented. In northwest Florida there is a trend of development on forestlands.

The study focused on three counties in northwestern Florida to serve as representative examples of areas of development and where restoring longleaf pine forests appeared to have potential as a competing use. Analysis of satellite imagery determined a loss of 38,763 ha (95,749 acres) of evergreen forest in Escambia, Okaloosa and Santa Rosa counties between 1992 and 2001. This is equal to a loss of 4,307 ha/year (10,638 acres/year).

Field measurement of carbon stocks in northwest Florida (supported by inventory data) revealed an estimated 45 metric tons of $\mathrm{C} / \mathrm{ha}$ (66.6 metric tons of $\mathrm{CO} 2$ equivalent/acre) in mature longleaf pine stands.

For the economic analysis two scenarios were considered for the conversion of industrial timberland to natural longleaf pine forest: clearcut and gradual conversion. Baselines for TIMO management and development were also included.

The gradual conversion strategy has both ecological and economic benefits. The economic benefit results from the staggered harvests over a 20 -year conversion period, allowing the timber crop to mature and yield a higher proportion of high value sawtimber relative to pulpwood. The greater significance of timber sale revenue results from: (1) the higher per unit value of timber products, and (2) timber revenue is realized in the first 20 years and is thus discounted less than the bulk of carbon benefits.

The TIMO baseline presents a clear economic disadvantage in that carbon revenue is delayed, at which point the discounted revenues from carbon pale in comparison to the considerable immediate, and un-discounted, cost of land acquisition (nearly $\$ 56$ million for 26,000 acres). Due to the land acquisition cost, none of the scenarios assessed even approached breaking-even (Table 5), nor did carbon revenues make a significant contribution to net present values (Table 6). Even at the higher price of $\$ 15$ per metric ton of $\mathrm{CO}_{2}$, land values would have to drop to around $\$ 300$ (immediate conversion with TIMO baseline), $\$ 540$ (gradual conversion), or $\$ 640$ per acre (immediate conversion with development baseline) to break even. 


\section{Task 6: Development of new project software screening tool}

Completed in the April-June 2005 quarter.

\section{Conclusions}

Many aspects of the research being carried out are still in their analysis stages. During the last three months a few of the topical reports from the first phase of the grant have been completed or are in draft form; from these certain conclusions can be highlighted. Below are the conclusions of: first, M3DADI study in the Delta National Forest; second, the cost comparison of report between the use of conventional and field techniques to estimate carbon storage; and third the longleaf pine baseline and feasibility study.

The application of M3DADI for estimating carbon stocks in a Bottomland Hardwood Forest showed that this type of system is able to measure carbon stocks effectively in bottomland forests. Equations were developed to link facets measurable from aerial imagery with biomass carbon. The available facets were tree height and crown area. Particular to the vegetation in the bottomland forests, the crown cover was single layered and dense, preventing frequent visibility of the ground and clear differentiation between trees. Consequently an equation was used that formed a straight line passing through the origin between crown area and biomass carbon. A biomass carbon value of $100 \mathrm{t} \mathrm{C/ha} \pm 7$ (mean $\pm 95 \%$ confidence interval) was determined through analysis of 30 aerial imagery plots (post correction for canopy distortion in regression equations). Due to immense difficulties in traversing bottomland forests (such as exists in Delta $\mathrm{NF}$ ) the costs can be high for stocks measured using ground data. A solution is to use aerial imagery such as M3DADI as was achieved in this study.

The cost comparison study of field techniques versus M3DADI for estimating carbon stocks found that the break-even point in person-hours, i.e. the number of plots where the field approach would cost the same as the M3DADI approach, is as follows: 29 plots for the pine savanna, 38 plots for the closed forest, and 26 plots for the bottomland forest. As all the forest types would require considerably more plots than the break even number for monitoring using the field approach, it is clear that the M3DAI approach is practically the most cost-effective choice for monitoring these systems. This analysis is based on comparing person hours needed rather than actual costs, thus translating this into dollar amounts could change the picture somewhat, but this depends on local costs for salaries, housing, food, vehicle rental etc. Given the amount of time for preparing, collecting and interpreting the data from both approaches, the effect of salaries on the actual dollar cost will vary greatly between the two approaches. For example, the level of skill needed for the M3DADI approach (GIS skills) is likely to be higher than for the conventional field approach and could command a higher pay scale per hour. However, this will vary as to whether local in-country technicians are used, as for example in Belize, where pay scales are likely to be lower than those for US-based technicians. In the US, there will be little difference between the pay scales of the field technicians and those of the GIS technicians. Other local costs such as transportation, housing and food would have to be factored in for a site specific cost comparison. Future possibilities of advanced in automated crown delineation, as discussed in a previous topical report, could also reduce costs of M3DADI analysis further. 
The feasibility and baseline study looking a opportunities for restoration of longleaf pine in north western Florida showed that the conversion of commercial pine forests to suburban development is the most advantageous carbon project baseline. As this is taking place rapidly and over extensive areas on the gulf coastal plain, the GCPEP region offers opportunities for siting longleaf pine restoration projects capable of generating and reporting demonstrable carbon benefits. We estimate here, an annual loss of 4,307 ha $(10,638)$ of timberland to development in the 3-county study region.

In terms of biodiversity and habitat structure it would undoubtedly be preferable to carry out partial cuts of the timberland with the planting of longleaf pine in the resulting gaps. Gradual conversion is also favored in economic analyses due to the benefits of higher timber yields in the maturing slash pine trees. However, at current land prices none of the scenarios even approached breaking even in the net present value analysis. 


\section{REFERENCES}

- Birdsey, R.A. 1996. Carbon storage for major forest types and regions in the conterminous United States. In: Sampson, R.N., Hair, D. (eds) Forests and Global Change, Volume 2: Forest Management Opportunities for Mitigating Carbon Emissions. American Forests, DC, USA. Pp. 1-26, 275.

- Birdsey, Richard A. 1996. Appendix 2 and Appendix 3, in Forests and Global Change, Volume 2: Forest Management Opportunities for Mitigating Carbon Emissions, American Forests: Washington, DC.

- Block, Nadine E., V. Alaric Sample. 2001. Industrial Timberland Divestitures and Investments: Opportunities and Challenges in Forestland Conservation. Pinchot Institute for Conservation Washington DC, USA. Pp 5, 9-11, 15.

- Boyer, W.D. 1993. Long-term development of regeneration under longleaf pine seedtree and shelterwood stands. Southern Journal of Applied Forestry 17: 10-15.

- Boyer, W.D. 2000. Long-term effects of biennial prescribed fires on the growth of longleaf pine. Pages 18-21 in W. Keith Moser and Cynthia F. Moser (eds.). Fire and forest ecology: innovative silviculture and vegetation management. Tall Timbers Fire Ecology Conference Proceedings, No. 21. Tall Timbers Research Station, Tallahassee, FL.

- Brown, S. 1997. Estimating Biomass and Biomass Change of Tropical Forests: A Primer. FAO Forestry Paper 134, Rome, Italy.

- Brown, S., Calmon, M. and Delaney, M. 2000. Development of a Deforestation and Forest

- Brown, S., L. R. Iverson, and A. E. Lugo. 1994. Use of GIS for estimating potential and actual forest biomass for continental South and Southeast Asia, pp. 67-116 in V. H. Dale (Ed.), The effect of land-use change on atmospheric $\mathrm{CO}_{2}$ concentrations, Springer-Verlag, New York.

- Brown, S., M. Delaney, D. Slaymaker, D. Shoch, W. Sabido, and D. Novelo. 2003. Estimating the Carbon Content of Pine-Savanna Vegetation in the Rio Bravo Carbon Sequestration Pilot Project Using Digital Aerial Imagery. Winrock International, Arlington, VA.

- Brown, S.L. and Schroeder, P.E. 1999. Spatial patterns of aboveground productions and mortality of woody biomass for eastern US forests. Ecological Applications 9: 968-980.

- Chomitz, K. 2002. Baseline, leakage and measurement issues: how do forestry and energy

- Dale, V H., R. V. O’Neill, M. Pedlowski, and F. Southworth. 1993. Causes and effects of land-use change in central Rondonia, Brazil. Photogrammetric Engineering and Remote Sensing 59:997-1005.

- Degradation Trend Model for the Guaraqueçaba Climate Action Project. Winrock International,

- Ducks Unlimited. 2003. Forest Change Detection in the Lower Mississippi Valley.

- Ebinger, M. H., D. A. Cremers, D. D. Breshears, P. J. Unkefer, S. A. Kammerdiener, M. J.Ferris. 
- Echeverria, C. and A. Lara. 2004. Growth patterns of secondary Nothofagus obliqua-N. Alpina

- Edmisten, J.E. 1963. The ecology of the Florida pine flatwoods. Ph.D. thesis, University of Florida, Gainesville.

- Florida Forever. Website. Dec. 20, 2004 $<$ http://www.dep.state.fl.us/lands/acquisition/FloridaForever/default.htm>

- forests in southern Chile. Forest Ecology and Management 195: 29-43.

- Gagnon, J.L., E.J. Jokela, W.K. Moser and D.A. Huber. 2003. Dynamics of artificial regeneration in gpas within a longleaf pine flatwoods ecosystem. Forest Ecology and Management 172: 133-144.

- Gayoso, J. and B. Schlegel. 2003. Estudio de línea de base de carbono: Carbono en bosques nativos, matorrales y praderas de la Décima Región de Chile. Universidad Austral de Chile, Valdivia, Chile.

- Gholz, H.L. and R.F. Fisher. 1982. Organic matter production and distribution in slash pine plantation ecosystems. Ecology 63:1827-1839.

- Gholz, H.L., Fisher, R.F., and W.L. Pritchett. 1985. Nutrient dynamics in slash pine plantation ecosystems. Ecology 66:647-659.

- Gonzalez, P., B. Kroll, and C.R. Vargas. 2004. Forest restoration carbon analysis in moist tropical forest at La Selva Central, Peru. Abstracts of the 89th Annual Meeting of the Ecological Society of America, August 1-6, 2004. Ecological Society of America, Washington, DC.

- Hall, C. A. S., H. Tian, Y. Qi, G. Pontius, J. Cornell and J. Uhlig, 1995a. Spatially explicit models of land use change and their application to the tropics. DOE Research Summary, No. 31. (Ed. by CDIAC, Oak Ridge National Lab); and Hall, C. A. S., H. Tian, Y. Qi, G. Pontius, J. Cornell and J. Uhlig, 1995 b. Modeling spatial and temporal patterns of tropical land use change. Journal of Biogeography 22: 753-757.

- Hall, Myrna and Dushku, Aaron. 2002. Spatial modeling of the averted deforestation baseline for the Noel Kempff Mercado Climate Action Project, Bolivia. Winrock International.

- Heyward, F. 1939. Some moisture relationships of soils from burned and unburned longleaf-pine forests. Soil Science 47: 313-325.

- Heyward, F. 1937. The effects of frequent fires on profile development on longleaf pine forest soils. Journal of Forestry 35: 23-27.

- Jenkins, J.C., Chojnacky, D.C., Heath, L.S. and R.A. Birdsey. 2003. Nationalscalebiomass estimators for United States tree species. Forest Science 49: 12-35.

- Kaimowitz, D. And A. Angelsen. 1998. Economic models of tropical deforestation: a review. Center for International Forestry Research, Bogor, Indonesia.

- Kant, Z., D. Gori, C. Enquist \& W. Parton. 2003. Carbon Sequestration and Semi-arid Grassland Restoration and Management in the Apache Highlands Ecological Region. The Nature Conservancy, Arlington, VA.

- Kant, Z., W. Parton \& M. Ebinger. 2003. Carbon Sequestration and Native Prairie Restoration in Kankakee Sands, Indiana. The Nature Conservancy, Arlington, VA. 
- Kreps, Brad. 2003. Establishing Land Cover Baselines and Prioritizing Sites for Reforestation for Carbon Sequestration and Reforestation of Mined Lands in the Clinch and Powell River Valleys. The Nature Conservancy, Arlington, VA.

- Kronrad, G. D., R. Bates, and C. Huang. 2002. Enhancement of Terrestrial Carbon Sinks Through Reclamation of Abandoned Mine Land in the Appalachian Region. Stephen Austin State University, Nagodoches, TX.

- Kush, J.S., W.D. Boyer, R.S. Meldahl and G.A. Ward. 1999. Precommercial thinning intensity in longleaf pine: effect on product volume and value. In Longleaf Pine: a Forward Look; Proceedings, Second Longleaf Pine Conference, 1998 November 17-19; Charleston, SC. Edited by John S. Kush. Longleaf Alliance Report No. 4 pp. 106-108.

- Laboratory, Los Alamos, NM.

- Laessle, A.M. 1942. The plant communities of the Welaka area with special reference to correlation between soils and vegetational succession. University of Florida, Gainesville.

- Markewitz, D., Sartori, F., and C. Craft. 2002. Soil change and carbon storage in longleaf pine stands planted on marginal agricultural lands. Ecological Applications 12(5): 1276-1285.

- McCulley, R.D. 1950. Management of natural slash pine stands in the flatwoods of south Georgia and north Florida. U.S. Department of Agriculture Circulation No. 845 .

- Mooney, S. 2003. Measurement and Monitoring Costs: influence of parcel contiguity, carbon variability, project size and timing of measurement events. Winrock International, Arlington, Virginia. $34 \mathrm{p}$

- Neira, E., P. Romero, and A. Lara. 2004. Complementación del estudio para el diseño de una línea de base para captura de Carbono en la Xma Región de Chile. Universidad Austral de Chile, Valdivia, Chile.

- Ober, L.D. 1954. Plant communities of the flatwood forests in Austin Cary Memorial Forest. M.S. thesis, University of Florida, Gaineville.

- Outcalt, K. 1993. Southern pines performance on sandhill sites in Georgia and South Carolina. Southern Journal of Applied Forestry 17: 100-102.

- Pearson, T., D. Shoch \& S. Brown. 2003. Carbon Sequestration Estimates for Bottomland Hardwood Restoration on Cropland. Winrock International, Arlington, VA

- Pearson, T., D. Shoch \& S. Brown. 2003. Feasibility for Carbon Sequestration through Bottomland Hardwood Restoration in Riparian Zones of the Susquehanna Watershed. Winrock International, Arlington, VA.

- Pienaar, L.V. and K.J. Turnbull. 1973. The Chapman-Richards Generalization of Von Bertalanffy's Growth Model for Basal Area Growth and Yield in Even-Aged Stands. Forest Science 19 (1): 2-22.

- Platt, W.J., G.W. Evans and S.L. Rathbun. 1988. The population dynamics of a long-lived conifer (Pinus palustris). The American Naturalist. Vol 131 (4): 491525.

- Pontius, G. 1994. Modeling tropical land use change and assessing policies to reduce carbon dioxide release from Africa. Ph.D. dissertation, State University of 
New York, Syracuse,New York; Tian, H. 1995. Spatial and temporal patterns of carbon flux and land use/cover at scales from landscape to the biosphere: an empirical study with observation and modeling. Ph.D. dissertation, State University of New York, Syracuse, New York; and Qi, Y. 1994. Human-induced biospheric change and the global carbon cycle: a spatialmodeling approach and its application to tropical Asia. Ph.D. dissertation, State University of New York, Syracuse, New York.

- projects compare? Climate Policy 2(1): 35-49.

- Results from the Field and Implications for Carbon Sequestration. Los Alamos National

- Richards, F.J. 1959. A flexible growth function for empirical use. Journal of Experimental Botany 10(29):290-300.

- RPA (Resources Planning Associates, Inc.) ECOPLOT software, Ithaca, NY

- Sande, Jon Bingen. 2003. Industrial Structures: Who Will Own the Forests? Vaxjo University International Conference on Forest Industry and Markets. 19 22 May 2003. Vaxjo, Sweden.

- Schlamadinger, B. and Marland, G. June, 2000. Land Use \& Global Climate Change: Forests, Land Management, and the Kyoto Protocol. The Pew Center on Global Climate Change.

- Schriever, J.R. \& R.G. Congalton. 1995. Evaluating seasonal variability as an aid to cover-type mapping from Landsat Thematic Mapper data in the Northeast. Photogrammetric Engineering and Remote Sensing 61 (3):321-327.

- Shoch, D, Brown, S., Delaney, M. and Broadwell, R. 2002. An Assessment of Carbon Sequestration Potential of Longleaf Pine Restoration and Conservation in Georgia. A Winrock International Report to Oglethorpe Power Company. Pp. 32.

- Slaymaker, D.M., K.M.L. Jones, C.R. Griffin \& J.T. Finn. 1996. Mapping deciduous forests in southern New England using aerial videography and hyperclustered multi-temporal Landsat TM imagery. Pages 87-101 in Gap Analysis: A Landscape Approach to Biodiversity Planning, ASPRS, Bethesda, MD, USA

- Spanner, M.A., L.L. Pierce, D.L. Petersen \& S.W. Running. 1990. Remote sensing of temperate coniferous forest leaf area index: The influence of canopy closure, understory vegetation and background reflectance. International Journal of Remote Sensing 11(1)95-111

- Stoddard, H. 1969. Memoires of a Naturalist. University of Oklahoma Press. 303 pp.

- Total Carbon Measurement in Soils using Laser-Induced Breakdown Spectroscopy:

- Wahlenberg, W.G. 1946. Longleaf pine: Its use, ecology, regeneration, protection, growth, and management. Charles Lathrop Pack Forestry Foundation and USDA Forest Service. Washington, DC $429 \mathrm{pp}$.

- Wilent, S.. 2004. Investors Increase Timberland Holdings. The Forestry Source Vol. 9, No.12. Bethesda, MD. Pp1-4. 
